Proceedings

\title{
Anti-Listerial Effect of 4-Hydroxyphenylpropanoic Acid Esters Synthesized by Lipase-Catalyzed Esterification ${ }^{+}$
}

\author{
Bartłomiej Zieniuk*, Ewa Białecka-Florjańczyk and Agata Fabiszewska
}

Citation: Zieniuk, B.; BiałeckaFlorjańczyk, E.; Fabiszewska, A. Anti-Listerial Effect of 4-Hydroxyphenylpropanoic Acid Esters Synthesized by Lipase-Catalyzed Esterification. Proceedings 2021, 70, 17. https://doi.org/10.3390/ foods_2020-07700

Published: 10 November 2020

Publisher's Note: MDPI stays neutral with regard to jurisdictional claims in published maps and institutional affiliations.

Copyright: (C) 2020 by the authors. Licensee MDPI, Basel, Switzerland. This article is an open access article distributed under the terms and conditions of the Creative Commons Attribution (CC BY) license (http://creativecommons.org/licenses/by/4.0/).

\author{
Department of Chemistry, Institute of Food Sciences, Warsaw University of Life Sciences, \\ 159c Nowoursynowska St., 02-776 Warsaw, Poland; ewa_bialecka_florjanczyk@sggw.edu.pl (E.B.-F.); \\ agata_fabiszewska@sggw.edu.pl (A.F.) \\ * Correspondence: bartlomiej_zieniuk@sggw.edu.pl; Tel.: +48-22-59-37-621 \\ + Presented at the 1st International Electronic Conference on Food Science and Functional Foods, \\ 10-25 November 2020; Available online: https://foods_2020.sciforum.net/.
}

\begin{abstract}
Listeria monocytogenes - A Gram-positive intracellular bacteria is one of the most virulent foodborne pathogens. A common strategy used to control the growth of bacteria in food is using food additives. However, many bacterial species are resistant to food preservatives, and bacterial resistance can be natural or acquired. Therefore, there is a constant need to search for new compounds with antimicrobial properties. The purpose of the present study was to evaluate the efficiency of five (ethyl, butyl, hexyl, octyl, and decyl) esters of 4-hydroxyphenylpropanoic acid against L. monocytogenes PCM 2191. Esters were obtained in reactions catalyzed by Candida antarctica lipase B. Purified esters with structures confirmed by ${ }^{1} \mathrm{H}$ NMR were applied to determine minimal inhibitory concentrations (MIC) using the microdilution broth method. MIC values ranged 0.0625-16 $\mathrm{mM}$. The results of this study have demonstrated the potential application of 4-hydroxyphenylpropanoic acid alkyl esters in inhibiting the growth of L. monocytogenes. Octyl 4-hydroxyphenylpropanoate proved to be the best antimicrobial agent and was used in a time-kill assay with different concentrations of $1 \times \mathrm{MIC}, 4 \times \mathrm{MIC}$, and $16 \times \mathrm{MIC}$. Three to nine $\log$ reduction of cell number were observed compared to control medium without any antimicrobial compound after $24 \mathrm{~h}$, and the possibility of using octyl 4-hydroxyphenylpropanoate in food applications is worth further investigation.
\end{abstract}

Keywords: biocatalysis; Candida antarctica lipase B; food additives; 4-hydroxyphenylpropanoic acid esters; Listeria monocytogenes

\section{Introduction}

In 2017, thirty European countries reported 2502 cases of listeriosis, which is a dangerous infection with a different clinical presentation from febrile gastroenteritis to severe invasive infections including sepsis, meningitis, perinatal infections, and abortions. The mentioned infection is caused by Listeria monocytogenes-a Gram-positive intracellular foodborne bacteria. Especially vulnerable groups of risk of bacterial infections are defined by a common abbreviation YOPI, which stands for Young, Old, Pregnant, and Immunosuppressed persons. Although the incidence of listeriosis is low, this disease poses a serious threat to public health due to very high mortality [1-3].

A common strategy used to control the growth of bacteria in food is using food additives. However, many bacterial species are resistant to food preservatives, and moreover, some of the additives arouse controversy among consumers. Given this, there is a constant need to search for new food preservatives with antimicrobial properties. The most needed are compounds synthesized in processes that cause less environmental pollution, less energy consumption, and in which fewer by-products are generated, and milder reaction conditions are used [4]. A great example of such a process is the use of 
green chemistry methods, e.g., enzymatically catalyzed reactions, which match the previously mentioned features [5].

The purpose of the present study was to evaluate the efficiency of five (ethyl, butyl, hexyl, octyl, and decyl) enzymatically obtained esters of 4-hydroxyphenylpropanoic acid against L. monocytogenes PCM 2191. Moreover, the antimicrobial potential of one of them-octyl 4-hydroxyphenylpropanoate-was also investigated in the time-kill assay.

\section{Materials and Methods}

\subsection{Microorganism}

Listeria monocytogenes PCM 2191 was purchased from the Polish Collection of Microorganisms (PCM) of Institute of Immunology and Experimental Therapy Polish Academy of Sciences (Wrocław, Poland).

\subsection{Materials}

Candida antarctica lipase B (CALB) was purchased from Sigma-Aldrich (Poznań, Poland). Culture media components were bought from BTL Sp. z o. o. (Łódź, Poland). Chemicals were acquired from Avantor Performance Materials Poland S.A. (Gliwice, Poland) and Sigma-Aldrich.

\subsection{Esters Synthesis, Purification, and Identification}

Syntheses of five esters were carried out with CALB (addition of $5 \%$ by weight of substrates) as biocatalyst. 4-Hydroxyphenylpropanoic acid alkyl esters were synthesized by reacting mentioned phenolic acid with alcohol (ethanol, 1-butanol, 1-hexanol, 1-octanol, and 1-decanol) in a molar ratio 1:1.5 (acid:alcohol). Reactions were carried out in flasks in methyl-tert-butyl ether at $37^{\circ} \mathrm{C}$ (Figure 1).

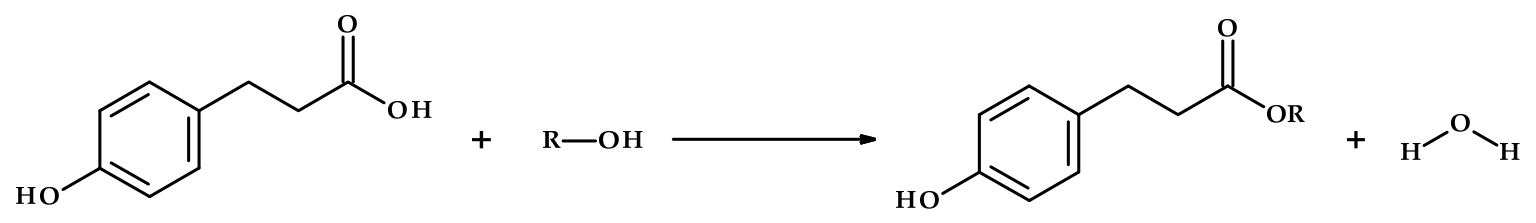

Figure 1. Lipase-catalyzed synthesis of 4-hydroxyphenylpropanoic acid alkyl esters. $\mathrm{R}=\mathrm{CH}_{3} \mathrm{CH}_{2-}, \mathrm{CH}_{3}\left(\mathrm{CH}_{2}\right)_{3-}, \mathrm{CH}_{3}\left(\mathrm{CH}_{2}\right)_{5-}$, $\mathrm{CH}_{3}\left(\mathrm{CH}_{2}\right)_{7-}$, or $\mathrm{CH}_{3}\left(\mathrm{CH}_{2}\right)_{9-}$.

After the reaction, the enzyme was separated from the reactants by filtration, and the solvent was evaporated. Esters were purified using column chromatography, silica gel 60 $(0.040-0.063 \mathrm{~mm} ; 230-400 \mathrm{mesh})$ was used as a stationary phase, and a mixture of chloroform and methanol (9:1) was applied as a mobile phase. Subsequently, ester-containing fractions were dried with $\mathrm{MgSO}_{4}$, filtered, and the mixture of solvents was evaporated.

The ${ }^{1} \mathrm{H}$ NMR spectra were measured using Bruker AVANCE $300 \mathrm{MHz}$ (USA) and $\mathrm{CDCl}_{3}$ was used as a solvent. Proton chemical shifts are reported below in ppm $(\delta)$ relative to tetramethylsilane (TMS) as an internal standard.

Ethyl 4-hydroxyphenylpropanoate ${ }^{1} \mathrm{H}$ NMR $\left(300 \mathrm{MHz}, \mathrm{CDCl}_{3}\right): \delta 1.23(3 \mathrm{H}, \mathrm{t}, J=7.3 \mathrm{~Hz})$, $2.59(2 \mathrm{H}, \mathrm{t}, J=7.8 \mathrm{~Hz}), 2.88(2 \mathrm{H}, \mathrm{t}, J=7.8 \mathrm{~Hz}), 4.12(2 \mathrm{H}, \mathrm{q}, J=6.6 \mathrm{~Hz}), 5.18(1 \mathrm{H}, \mathrm{s}), 6.70-6.80$ $(2 \mathrm{H}, \mathrm{m}), 7.00-7.10(2 \mathrm{H}, \mathrm{m})$.

Butyl 4-hydroxyphenylpropanoate ${ }^{1} \mathrm{H}$ NMR $\left(300 \mathrm{MHz}, \mathrm{CDCl}_{3}\right): \delta 0.91(3 \mathrm{H}, \mathrm{t}, J=7.3 \mathrm{~Hz})$, $1.34(2 \mathrm{H}, \mathrm{m}), 1.58(2 \mathrm{H}, \mathrm{m}), 2.59(2 \mathrm{H}, \mathrm{t}, J=7.8 \mathrm{~Hz}), 2.88(2 \mathrm{H}, \mathrm{t}, J=7.8 \mathrm{~Hz}), 4.07(2 \mathrm{H}, \mathrm{t}, J=6.6$ $\mathrm{Hz}), 4.99(1 \mathrm{H}, \mathrm{s}), 6.70-6.79(2 \mathrm{H}, \mathrm{m}), 7.02-7.10(2 \mathrm{H}, \mathrm{m})$.

Hexyl 4-hydroxyphenylpropanoate ${ }^{1} \mathrm{H}$ NMR $\left(300 \mathrm{MHz}, \mathrm{CDCl}_{3}\right): \delta 0.89(3 \mathrm{H}, \mathrm{t}, J=7.3 \mathrm{~Hz})$, $1.29(6 \mathrm{H}, \mathrm{m}), 1.60(2 \mathrm{H}, \mathrm{m}), 2.59(2 \mathrm{H}, \mathrm{t}, J=7.8 \mathrm{~Hz}), 2.88(2 \mathrm{H}, \mathrm{t}, J=7.8 \mathrm{~Hz}), 4.06(2 \mathrm{H}, \mathrm{t}, J=6.6$ $\mathrm{Hz}), 4.98(1 \mathrm{H}, \mathrm{s}), 6.70-6.80(2 \mathrm{H}, \mathrm{m}), 7.00-7.12(2 \mathrm{H}, \mathrm{m})$. 
Octyl 4-hydroxyphenylpropanoate ${ }^{1} \mathrm{H}$ NMR $\left(300 \mathrm{MHz}, \mathrm{CDCl}_{3}\right): \delta 0.88(3 \mathrm{H}, \mathrm{t}, J=7.3 \mathrm{~Hz})$, $1.28(10 \mathrm{H}, \mathrm{m}), 1.60(2 \mathrm{H}, \mathrm{m}), 2.59(2 \mathrm{H}, \mathrm{t}, J=7.8 \mathrm{~Hz}), 2.88(2 \mathrm{H}, \mathrm{t}, J=7.8 \mathrm{~Hz}), 4.05(2 \mathrm{H}, \mathrm{t}, J=$ $6.6 \mathrm{~Hz}), 4.97(1 \mathrm{H}, \mathrm{s}), 6.70-6.78(2 \mathrm{H}, \mathrm{m}), 7.02-7.10(2 \mathrm{H}, \mathrm{m})$.

Decyl 4-hydroxyphenylpropanoate ${ }^{1} \mathrm{H}$ NMR $\left(300 \mathrm{MHz}, \mathrm{CDCl}_{3}\right): \delta 0.88(3 \mathrm{H}, \mathrm{t}, J=7.3 \mathrm{~Hz})$, $1.26(14 \mathrm{H}, \mathrm{m}), 1.61(2 \mathrm{H}, \mathrm{m}), 2.58(2 \mathrm{H}, \mathrm{t}, J=7.8 \mathrm{~Hz}), 2.88(2 \mathrm{H}, \mathrm{t}, J=7.8 \mathrm{~Hz}), 4.05(2 \mathrm{H}, \mathrm{t}, J=$ $6.6 \mathrm{~Hz}), 4.86(1 \mathrm{H}, \mathrm{s}), 6.70-6.78(2 \mathrm{H}, \mathrm{m}), 7.01-7.11(2 \mathrm{H}, \mathrm{m})$.

\subsection{Determination of Minimum Inhibitory Concentration and Minimum Bactericidal Concentration}

The minimum inhibitory concentration (MIC) of esters and their precursor-4-hydroxyphenylpropanoic acid - was determined by the microdilution broth method according to ISO [6]. Furthermore, minimum bactericidal concentrations (MBC) were determined [5].

\subsection{Time-Kill Assay}

The survival of L. monocytogenes PCM 2191 by the time-kill assay was investigated in Mueller-Hinton medium by treating the bacterial strain to the following concentrations of octyl 4-hydroxyphenylpropanoate: $1 \times$ MIC $(0.0625 \mathrm{mM}), 4 \times \mathrm{MIC}(0.25 \mathrm{mM})$, and $16 \times$ MIC (1 mM). In each flask, there was a total of $100 \mathrm{~mL}$ of mentioned medium, ester as an antimicrobial agent, and bacterial suspension with an initial density approximately of $10^{6}$ $10^{7} \mathrm{CFU} / \mathrm{mL}$. During $24 \mathrm{~h}$ incubation at $37^{\circ} \mathrm{C}$, samples were withdrawn from the cultures at $0,2,4,8$, and $24 \mathrm{~h}$, and after diluting in $0.85 \%$ saline, they were cultured in TSA (Tryptic Soy Agar) medium at $37^{\circ} \mathrm{C}$ for $24 \mathrm{~h}$. Subsequently, the colonies were counted, and the results were presented in logarithmic scale as $\log \mathrm{CFU} / \mathrm{mL}$.

Moreover, optical density measurements at $600 \mathrm{~nm}$ were made for comparison using $\mathrm{UV} /$ Vis spectrophotometer.

\section{Results and Discussion}

Due to the growing problem of foodborne microorganisms and their resistance to different antimicrobials, searching for new compounds is a focus of scientific attention. In order to be suitable for use as food additives, the tested compounds should exhibit high biological activity. Therefore, after carrying out enzyme-catalyzed reactions, purifying the compounds, and confirming their structure, the MIC and MBC values of the obtained esters were determined and compared with the values obtained for 4-hydroxyphenylpropanoic acid. The results are presented in Table 1.

Table 1. Antimicrobial activities of 4-hydroxyphenylpropanoates and their precursor expressed as minimal inhibitory concentrations (MIC) and minimal bactericidal concentrations (MBC).

\begin{tabular}{ccc}
\hline Compound & MIC [mM] & MBC [mM] \\
\hline 4-Hydroxyphenylpropanoic acid & 16 & 32 \\
Ethyl 4-hydroxyphenylpropanoate & 8 & 16 \\
Butyl 4-hydroxyphenylpropanoate & 2 & 4 \\
Hexyl 4-hydroxyphenylpropanoate & 0.5 & 1 \\
Octyl 4-hydroxyphenylpropanoate & 0.0625 & 0.25 \\
Decyl 4-hydroxyphenylpropanoate & 0.25 & 1 \\
\hline
\end{tabular}

MIC values ranged $0.0625-16 \mathrm{mM}$, and MBC values were $0.25-32 \mathrm{mM}$. It has been shown that anti-listerial activity increased with increasing the chain length of the alkyl part of the ester, except for decyl 4-hydroxyphenylpropanoate, where MIC and MBC values began to rise again. Octyl 4-hydroxyphenylpropanoate turned out to be the most active compound against $L$. monocytogenes PCM 2191 with $\mathrm{MIC}=0.0625 \mathrm{mM}$ and $\mathrm{MBC}=0.25$ $\mathrm{mM}$. The esterification of phenolic acid allowed obtaining more active compounds compared to their precursor, which is related to increased lipophilicity - a term that was also discussed by Shi et al. [7]. 
Shi et al. [7] examined six different ferulic acid alkyl esters against L. monocytogenes ATCC 19115 and noted that MIC and MBC values first decreased and then increased with increasing the chain length, where the highest activity was observed for butyl and hexyl ferulates [7].

In the next stage of the research, octyl 4-hydroxyphenylpropanoate was used in the time-kill assay. Growth curves of treatment of L. monocytogenes with ester in different concentrations are presented in Figure 2. In addition, the growth of bacteria under the described experimental conditions was also determined by measuring the optical density (Figure 3).

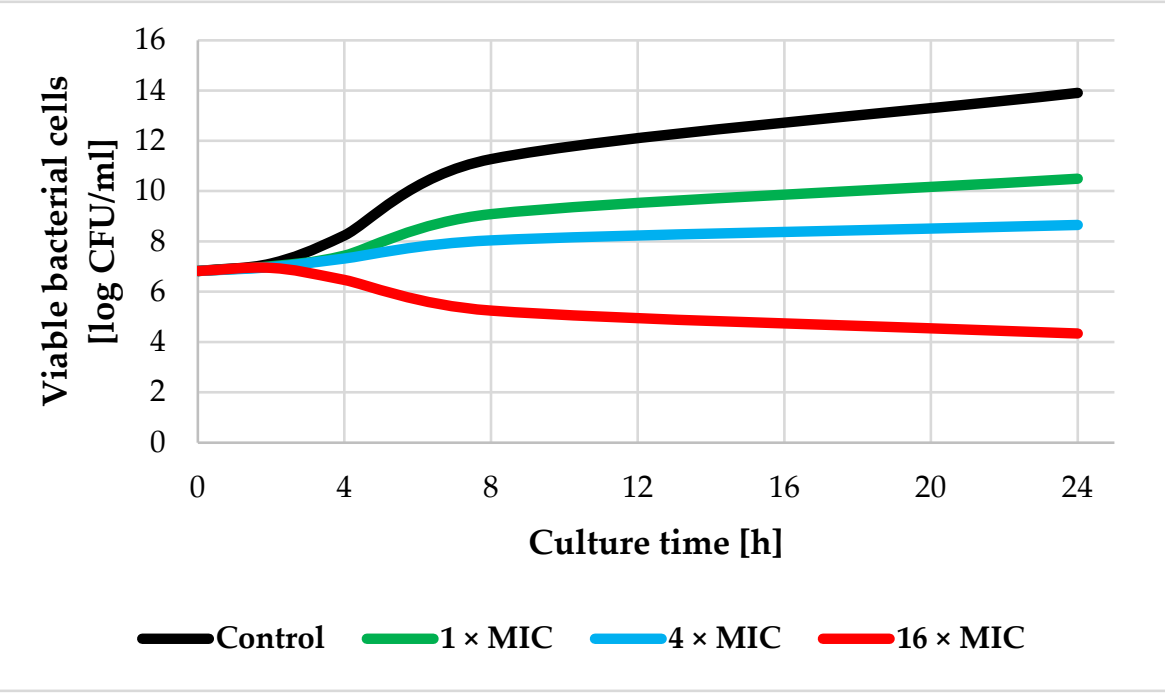

Figure 2. Time-kill curves of Listeria monocytogenes PCM 2191 treated with different concentrations of octyl 4-hydroxyphenylpropanoate, i.e., $1 \times$ MIC $(0.0625 \mathrm{mM}), 4 \times \mathrm{MIC}(0.25 \mathrm{mM})$, and $16 \times \mathrm{MIC}$ (1 mM).



Figure 3. Optical density measurement at $600 \mathrm{~nm}$ of Listeria monocytogenes PCM 2191 without or with octyl 4-hydroxyphenylpropanoate at $1 \times \mathrm{MIC}(0.0625 \mathrm{mM}), 4 \times \mathrm{MIC}(0.25 \mathrm{mM})$, and $16 \times \mathrm{MIC}$ $(1 \mathrm{mM})$.

The concentration-dependent anti-listerial activity of octyl 4-hydroxyphenylpropanoate can be observed. Bacteria rapidly grew in the medium without any antimicrobials, and after $24 \mathrm{~h}$, the number of viable cells increased by 7 log cycles. A significant difference between the media was also noticeable by observing the optical density measurement (Figure 3 ). Tested ester at $1 \times$ MIC and $4 \times$ MIC led to limiting the growth of bacteria. This 
indicates that synthesized molecule demonstrated bacteriostatic activity, which is also confirmed by the MBC/MIC ratio, which amounted to 4 . According to Konate et al. [8], when the MBC/MIC ratio was 1-2, the effect of the antimicrobial agent was defined as bactericidal, and when this ratio ranged $4-16$, the effect was considered as bacteriostatic. The use of octyl 4-hydroxyphenylpropanoate at $1 \times$ MIC and $4 \times$ MIC reduced the growth of L. monocytogenes PCM 2191 by 3 and $5 \log$ CFU $/ \mathrm{mL}$ compared to the control medium, and the bacterial cell number was 10.49 and $8.66 \log \mathrm{CFU} / \mathrm{mL}$, respectively.

Only the use of octyl 4-hydroxyphenylpropanoate at the highest concentration of 16 $\times$ MIC $(1 \mathrm{mM})$ resulted in the reduction of the number of bacteria. The killing effect has been already observed after $4 \mathrm{~h}$, when the number of cells was reduced compared to their initial value. The decline in cell numbers progressed over time. After $24 \mathrm{~h}$, cell viability in this medium was determined to be $4.33 \log \mathrm{CFU} / \mathrm{mL}$, which is about $2.5 \log$ cycles less compared to the number of the cell at $0 \mathrm{~h}$. When comparing the number of bacteria after $24 \mathrm{~h}$ in the control medium and the $16 \times$ MIC medium, a radical difference of approximately $9 \log$ cycles is noticeable.

\section{Conclusions}

To summarize, it was proven that 4-hydroxyphenylpropanoic acid esters synthesized by lipase-catalyzed esterification exhibited antibacterial activity toward L. monocytogenes PCM 2191. Enzymatic reactions allowed obtaining more active compounds compared to their carboxyl precursor, and anti-listerial activity increased with increasing the alkyl chain length. Time-kill assay revealed that octyl 4-hydroxyphenylpropanoate was able to limit the number of bacteria cells, and concentration-dependent activity was observed. Moreover, the possibility of using octyl 4-hydroxyphenylpropanoate in food applications is worth further investigation. Economical and environmentally friendly methods of enzymatic synthesis of new food additives should be also further developed.

Author Contributions: Conceptualization, B.Z.; methodology, B.Z. and E.B.-F.; formal analysis and investigation, B.Z.; writing - original draft preparation, B.Z. and A.F.; writing-review and editing, B.Z., A.F., and E.B.-F.; visualization, B.Z.; supervision, E.B.-F. All authors have read and agree to the published version of the manuscript.

Conflicts of Interest: The authors declare no conflict of interest.

\section{References}

1. Kuch, A.; Goc, A.; Belkiewicz, K.; Filipello, V.; Ronkiewicz, P.; Gołębiewska, A.; Wróbel, I.; Kiedrowska, M.; Waśko, I.; Hryniewicz, W.; et al. Molecular diversity and antimicrobial susceptibility of Listeria monocytogenes isolates from invasive infections in Poland (1997-2013). Sci. Rep. 2018, 8, 14562.

2. Allerberger, F.; Wagner, M. Listeriosis: A resurgent foodborne infection. Clin. Microbiol. Infect. 2010, 16, 16-23.

3. European Centre for Disease Prevention and Control. Listeriosis-Annual Epidemiological Report for 2017. Available online: https://www.ecdc.europa.eu/sites/default/files/documents/listeriosis-annual-epidemiological-report-2017.pdf (accessed on 9 October 2020).

4. Anastas, P.T.; Zimmerman, J.B. The United Nations sustainability goals: How can sustainable chemistry contribute? Curr. Opin. Green Sustain. Chem. 2018, 13, 150-153.

5. Zieniuk, B.; Wołoszynowska, M.; Białecka-Florjańczyk, E.; Fabiszewska, A. Synthesis of Industrially Useful Phenolic Compounds Esters by Means of Biocatalysts Obtained Along with Waste Fish Oil Utilization. Sustainability 2020, $12,5804$.

6. International Organization for Standards. ISO 20776-1. Clinical laboratory Testing and In Vitro Diagnostic Test Systems-Susceptibility Testing of Infectious Agents and Evaluation of Performance of Antimicrobial Susceptibility Test Devices-Part 1: Reference Method for Testing the In Vitro Activity of Antimicrobial Agents against Rapidly Growing Aerobic Bacteria Involved in Infectious Diseases; International Organization for Standards: Geneva, Switzerland, 2006.

7. Shi, Y.G.; Bian, L.Q.; Zhu, Y.J.; Zhang, R.R.; Shao, S.Y.; Wu, Y.; Chen, Y.W.; Dang, Y.L.; Ding, Y.; Sun, H. Multifunctional alkyl ferulate esters as potential food additives: Antibacterial activity and mode of action against Listeria monocytogenes and its application on American sturgeon caviar preservation. Food Control 2019, 96, 390-402.

8. Konate, K.; Hilou, A.; Mavoungou, J.F.; Lepengue, A.N.; Souza, A.; Barro, N.; Datte, J.Y.; M’Bachti, B.; Nacoulma, O.G. Antimicrobial activity of polyphenol-rich fractions from Sida alba L. (Malvaceae) against co-trimoxazol-resistant bacteria strains. Ann. Clin. Microbiol. Antimicrob. 2012, 11, 5. 